\title{
CORRESPONDENCE
}

\section{SOME PROBLEMS OF GEOMORPHOLOGY AND CONTINENTAL RELATIONSHIPS IN BRITISH GUIANA}

Sir,-The article by Mr. D. W. Bishopp, published in the July-August number of the Geological Magazine, contains some inaccurate and misleading statements about the geology of West Africa, which I feel should not pass without comment.

(I) Kawere Formation.-This Gold Coast formation, locally known as the "Kawere Group", is not of Upper Birrimian age, and it does not contain any volcanic agglomerates. Ii belongs to the Tarkwaian (not Tarquaian) System which is separated from the Upper Birrimian by a major unconformity.

(2) Trend Lines.-The average trend of the foliations and fold lines in the rocks of the Basement Complex is approximately north-east in the Gold Coast, and between north-west and north in Sierra Leone, and not north-north-east as stated by Mr. Bishopp.

(3) Voltaian Escarpment.-This escarpment is from 50 to 150 miles from the coast and not $300 \mathrm{~km}$., and is not due to faulting.

(4) Gorceixite.-Mr. Bishopp states: "An important mineralogical resemblance is provided by the recent discovery (du Toit, 1937) in the Gold Coast of rolled specimens of gorceixite, hitherto known only in Brazil." His reference to "du Toit, 1937" is incorrect. This mineral was found by me near Tarkwa in I936, and was determined and analysed by Messrs. E. H. Beard and W. H. Bennett of the Imperial Institute. ${ }^{1}$ Since then $I$ have found it in diamondiferous gravels in Sierra Leone and in the Birim Valley (Gold Coast).

(5) Coast-line.-According to Mr. Bishopp, "the downfaulted nature of the coast-line in the Gold Coast is accepted." Detailed study has shown, however, that the coast-line is of composite origin and has been determined principally by the strike of the rocks. ${ }^{2}$ The younger sediments, Devonian, Carboniferous, and Cretaceous, all dip seawards towards the submarine trough which extends all the way from Cape Palmas (Liberia) to beyond the Gold Coast. This trough reaches a depth of 5 ,ooo6,oon metres, and its slope on the coastal side is steeper than the slope of any other part of the Atlantic coast of Africa. The

1 Annual Report of the Gold Coast Geological Survey, I937-38, p. 6.

2 Junner, N. R., Geology of the Gold Coast and Western Togoland, Bull. I I. Gold Coast Geological Survey, 1940, p. 34.

vol. LXxvm.-NO. 1 . 
trough has determined the east-west trend of this part of the African coast, and it appears to be a major tectonic feature. To the east it lines up with the Gretaceous-filled Benue depression in Nigeria, and to the west with the Amazon syncline, according to the restoration of the continents suggested by du Toit ${ }^{\mathbf{1}}$; between them is the only break of any depth in the Central Atlantic submarine ridge. The fact that fossiliferous Devonian and Carboniferous rocks are not known anywhere else in this part of Africa, although they occur in the Amazon syncline, is significant. That the trough is still active seems likely from the numerous submarine earthquakes recorded from the equatorial zone between Brazil and the Gold Coast.

As long ago as $\mathrm{I} 868$, Dr. Horton noted the great similarity in the geology of Brazil and the Gold Coast, and argued that : "These facts lead me to the belief that when the resources of the country (the Gold Coast) are much more developed, diamonds will be found not only in the eastern district, but also in the rivers and lagoons of Awoonah and Dahomey." 2 Since then many writers have stressed the similarities. Comparisons and correlations on lithological grounds of unfossiliferous sedimentary formations over great distances should, however, be accepted with reserve, and much less value should be attached to correlations of igneous rocks, such as granites, gabbros, and dolerites, unless their ages are known. In West Africa, for example, there are gabbros and dolerites of at least four different ages, and the Horizontal Sandstones, of which the Voltaian are part, probably range in age from Ordovician to Devonian or Carboniferous.

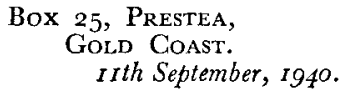

N. R. JUNNER.

1 A. L. du Toit, Our Wandering Continents, London, 1937, p. 108.

2 J. A. B. Horton, West African Countries and Peoples, 1868. 